Article

\title{
Deep Eutectic Solvents as Effective Reaction Media for the Synthesis of 2-Hydroxyphenylbenzimidazole- Based Scaffolds en Route to Donepezil-Like Compounds
}

\author{
Luca Piemontese ${ }^{1, *} \mathbb{*}$, Roberta Sergio ${ }^{1}$, Federica Rinaldo ${ }^{1}$, Leonardo Brunetti ${ }^{1}{ }^{1}$, \\ Filippo M. Perna ${ }^{1,2} \mathbb{C}$, M. Amélia Santos ${ }^{3}$ and Vito Capriati ${ }^{1,2, *(\mathbb{D}}$ \\ 1 Dipartimento di Farmacia-Scienze del Farmaco, Università degli Studi di Bari «Aldo Moro», \\ Via E. Orabona 4, I-70125 Bari, Italy; r.sergio2@studenti.uniba.it (R.S.); f.rinaldo@studenti.uniba.it (F.R.); \\ 1.brunetti2@studenti.uniba.it (L.B.); filippo.perna@uniba.it (F.M.P.) \\ 2 Consorzio C.I.N.M.P.I.S., Via E. Orabona 4, I-70125 Bari, Italy \\ 3 Centro de Química Estrutural, Instituto Superior Técnico, Universidade de Lisboa, Av. Rovisco Pais 1, \\ 1049-001 Lisboa, Portugal; masantos@ist.utl.pt \\ * Correspondence: luca.piemontese@uniba.it (L.P.); vito.capriati@uniba.it (V.C.); Tel.: +39-080-5442174 (V.C.) \\ Academic Editor: Paula Sério Branco

Received: 19 December 2019; Accepted: 27 January 2020; Published: 28 January 2020

Abstract: An unsubstituted 2-hydroxyphenylbenzimidazole has recently been included as a scaffold in a series of hybrids (including the hit compound PZ1) based on the framework of the acetylcholinesterase (AChE) inhibitor Donepezil, which is a new promising multi-target ligand in Alzheimer's disease (AD) treatment. Building upon these findings, we have now designed and completed the whole synthesis of PZ1 in the so-called deep eutectic solvents (DESs), which have emerged as an unconventional class of bio-renewable reaction media in green synthesis. Under optimized reaction conditions, the preparation of a series of 2-hydroxyphenylbenzimidazole-based nuclei has also been perfected in DESs, and comparison with other routes which employ toxic and volatile organic solvents (VOCs) provided. The functionalization of the aromatic ring can have implications on some important biological properties of the described derivatives and will be the subject of future studies of structure-activity relationships (SARs).

Keywords: deep eutectic solvents; 2-hydroxyphenylbenzimidazole; Alzheimer's disease

\section{Introduction}

Alzheimer's disease (AD) is recognized as a social and economic problem with an annual incidence of 34/1000 persons over 60 years old [1-4]. It is estimated that, in the absence of effective therapies, the number of people with dementia will reach more than 130 million worldwide by 2050 [5]. Although numerous clinical trials have been projected and realized [5-7], only five symptomatic drugs have been approved to date for the use as anti-AD agents at international level. Tacrine, which represented the first breakthrough in the AD therapy, has been discontinued from the market in several countries because of its severe adverse events [8].

Considering the specific pathogenesis of $\mathrm{AD}$, a new generation of ligands has recently been explored as multifunctional molecules aimed at simultaneously acting on two or more disease features (multi-target directed ligands) so as to achieve synergistic or at least complementary therapeutic effects. The model based on the "one molecule/multiple targets" concept has led to the design of novel molecules frequently inspired by natural products or bio-active synthetic molecules [2]. The most explored strategy for multi-target anti-AD drugs is based on the "cholinergic hypothesis". 
This involves the repositioning of drugs already used in therapy such as tacrine, donepezil, memantine, rivastigmine [2,9-11] as starting molecules to hit other AD targets [12]. According to the so-called "metal hypothesis", several metal-chelating moieties have been incorporated in these structures $[5,7,8]$. Indeed, the biometal dyshomeostasis (copper and zinc cations but also iron and aluminum) in AD is known to be involved in A $\beta$ aggregation [13-15]. Moreover, the redox activity of these ions may lead to the formation of reactive oxygen species (ROS), which are known to play an important role in chronic inflammation eventually responsible for the oxidative stress of neuronal cells [2,6,16-18].

In the last years, our research groups have synthesized and assayed new multi-functional ligands with chelating abilities towards $\mathrm{Cu}^{2+}$ and $\mathrm{Zn}^{2+}$, potentially useful in the $\mathrm{AD}$ treatment based on the framework of the acetylcholinesterase (AChE) inhibitor Donepezil and 2-hydroxyphenylbenzimidazole [19-21]. Benzimidazole-based nuclei have been the subject of intense investigation in recent years as they proved to be important scaffolds for the preparation of other bioactive compounds [22-25]. For example, they have been included in several drugs and drug-like candidates such as the antihypertensive drug Telmisartan and the antiviral drug Maribavir, in several anti-inflammatory and antiulcer agents like the blockbuster drug Omeprazole [22,23], and in various $\beta$-secretase (BACE1) inhibitors and other AD targets [25-27].

Because of stringent environmental legislation to address the climate crisis, urgent actions are needed to be taken in the chemical production, in particular, to progressively replace extensively used conventional and often hazardous volatile organic compounds (VOCs), which are known to contribute to over $80 \%$ of the organic waste produced, in favor of safer and more environmentally responsible solvents. In this context, the so-called deep eutectic solvents (DESs) have emerged as a novel promising class of green solvents as they are non-flammable, highly thermally stable, with practically no vapor pressure, and thus low volatility [28]. They are combination of two or three safe and cheap components (Lewis or Bronsted acids and bases, which can contain a variety of anionic and/or cationic species) that form, through hydrogen bond formation, a eutectic liquid mixture at a temperature far below than that of either of the individual components. Typical DES components come from renewable sources [e.g., choline chloride $(\mathrm{ChCl})$, glycerol (gly), urea, natural carboxylic acids, amino acids, polyalcohols]. Therefore, their biodegradability is high and their toxicity is non-existent or very low. In addition, they can be easily prepared and exhibit tunable physicochemical properties [28]. Because of their ability to act also as catalysts and reagents [29,30], DESs have been primarily investigated in extraction and separation processes [31-34], in material sciences [35], for metal electrodeposition [36], and for the synthesis of heterocycles [37]. Emerging and hot fields of applications are represented by organometallics [38-40], metal- [41-48], bio- [49-53], and organo-catalysis [54-57], electrochemistry [58], photosynthesis [59] and energy technology [60,61]. Building upon our interests in the synthesis of drugs and heterocycles using eco-friendly reaction media like DESs [43-47,55,62,63] and water [64], herein we report the sustainable preparation of several 2-hydroxyphenylbenzimidazole derivatives and the whole synthesis of PZ1 [19] in selected eutectic mixtures.

\section{Results and Discussion}

The role played by $\mathrm{Zn}$ and $\mathrm{Cu}$ cations in the $\mathrm{A} \beta$ deposition and stabilization has been a matter of debate in the literature in the last decade as well as the possibility that metal chelating agents can lead to the dissolution of $\mathrm{A} \beta$ and/or aggregation by preventing the interaction between the metal and the protein $[2,11,17,21,65-69]$. According to the metal hypothesis of AD, it is important the inclusion of chelating moieties in the design of therapeutic/diagnostic agents [69]. Our groups recently focused on the synthesis and the biological evaluation of new Donepezil-like conjugates, and especially interesting were the results obtained from biological assays on PZ1 [19-21]. The synthesis of this new hit compound was designed using VOCs ([19], Figure 1, red). Particularly disappointing from an environmental viewpoint were Steps 2, 4 and 5 in which it was made use of toxic and anhydrous $\mathrm{CH}_{3} \mathrm{CN}$ (step 2), N,N-dimethylacetamide (DMA) (Step 4), N,N-dimethylformamide (DMF) (Step 5), and of a carcinogenic reactant like hydrazine hydrate in Step 3. In addition, Step 4 also required up to 
$12 \mathrm{~h}$ reaction time for completion. Thus, we decided to reshape the whole synthesis of PZ1 using DESs as environmentally responsible reaction media (Figure 1, blue).<smiles>NCCN1CCNCC1</smiles><smiles></smiles><smiles>O=C1c2ccccc2C(=O)N1CCN1CCNCC1</smiles>

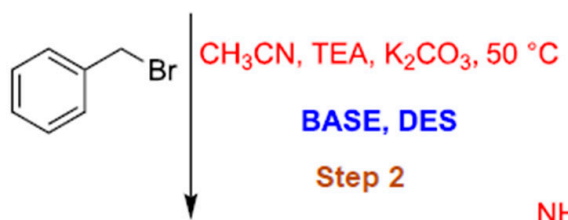<smiles>O=C1c2ccccc2C(=O)N1CCN1CCN(Cc2ccccc2)CC1</smiles>

Classical synthesis of PZ1 [19]

This work

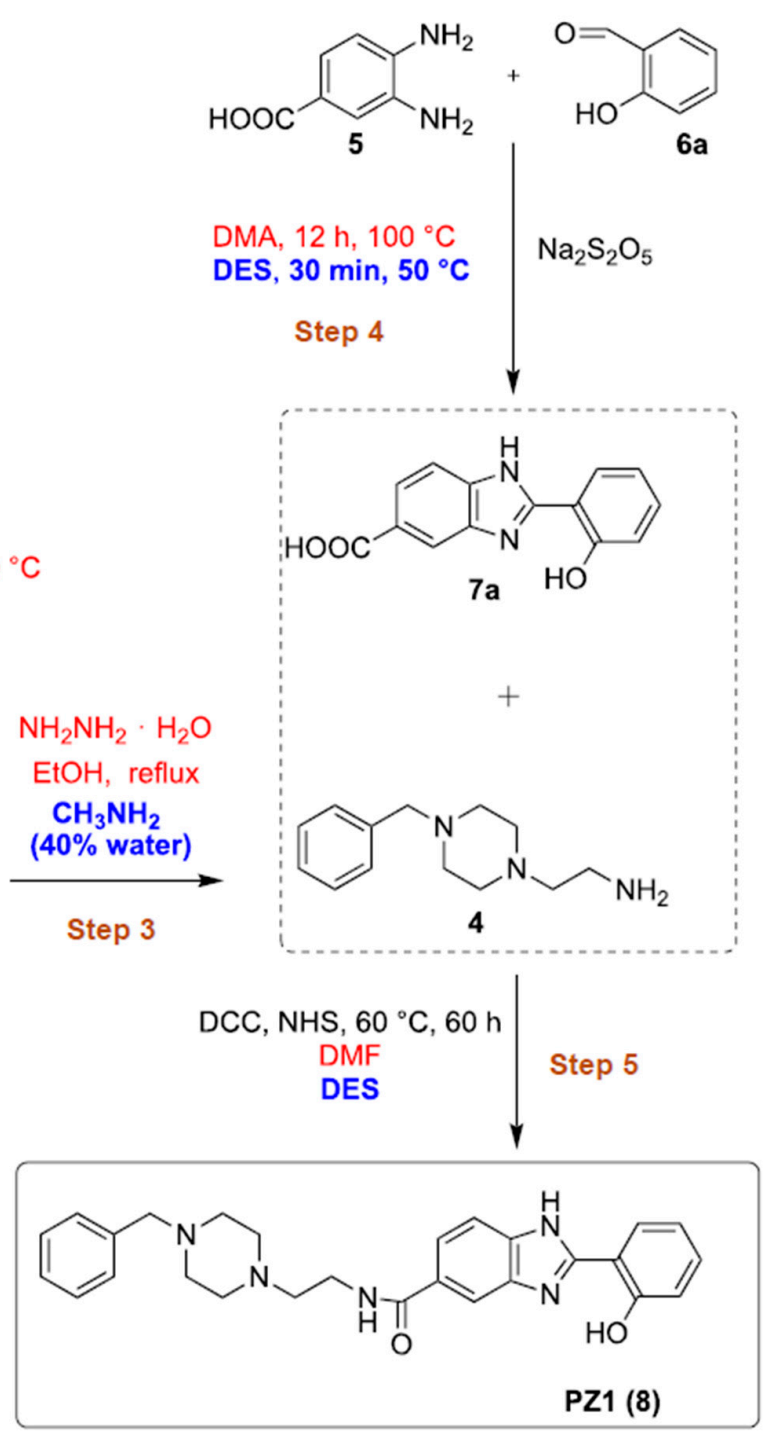

Figure 1. Classical (red, [19]) and new green (blue) procedure for the synthesis of PZ1.

The selective protection of the primary amine moiety of $\mathbf{1}$, performed by reacting $\mathbf{1}$ with phthalic acid anhydride at $180{ }^{\circ} \mathrm{C}$ for $5 \mathrm{~h}$ under solventless conditions, delivered adduct 2 in quantitative yield (>98\% yield) $[19,70]$ (Figure 1, Step 1). The benzylation of the secondary amine of the piperazine moiety of 2 en route to adduct 3 (Figure 1, Step 2) was originally carried out in acetonitrile and in the presence of a couple of bases, used in excess (64\% yield) (Table 1, entry 1). An extensive screening of bases $\left[\mathrm{KOH}, t-\mathrm{BuOK}, \mathrm{K}_{2} \mathrm{CO}_{3}\right.$, triethylamine (TEA)] in different hydrophilic $[28,71,72]$ and hydrophobic [73] eutectic mixtures as solvents, at a temperature of 50 or $100{ }^{\circ} \mathrm{C}$ (Table 1 ), revealed that TEA (2 equiv) either in $\mathrm{ChCl} /$ propylene glycol (PG) $\left(1: 3 \mathrm{~mol} \mathrm{~mol}^{-1}\right)$ or in $\mathrm{Bu}_{4} \mathrm{NCl} / \mathrm{gly}\left(1: 4 \mathrm{~mol} \mathrm{~mol}^{-1}\right)$ [72] were the best combinations as they delivered 3 in 64-68\% yield (Table 1, entries 15,19). 
Table 1. Optimization of the benzylation reaction for the synthesis of 3. ${ }^{\text {a }}$

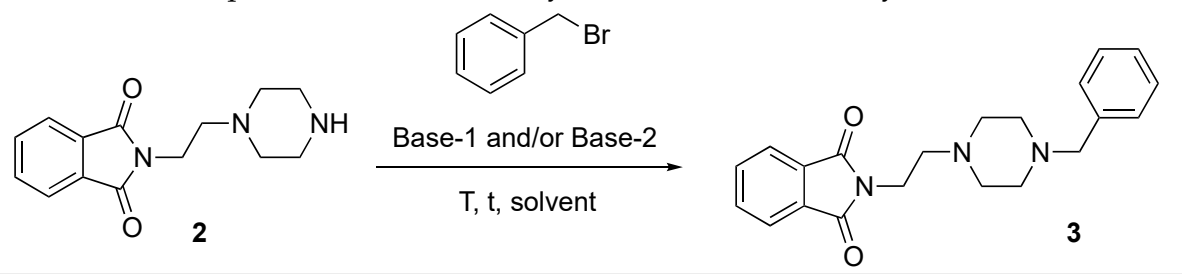

\begin{tabular}{|c|c|c|c|c|c|c|c|}
\hline Entry & Base-1 (Equiv) & Base-2 (Equiv) & BnBr (Equiv) & $\mathrm{T}\left({ }^{\circ} \mathrm{C}\right)$ & $\mathrm{T}$ (h) & Solvent & 3, Yield $(\%)^{b}$ \\
\hline 1 & TEA (1.4) & $\mathrm{K}_{2} \mathrm{CO}_{3}(6.6)$ & 2.3 & 50 & 3 & $\mathrm{CH}_{3} \mathrm{CN}$ & $64^{c}$ \\
\hline 2 & $\mathrm{KOH}(1.1)$ & - & 1.0 & 50 & 24 & $\mathrm{ChCl} / \mathrm{gly}$ & $N R^{d}$ \\
\hline 3 & $\mathrm{KOH}(1.1)$ & - & 1.0 & 50 & 24 & $\mathrm{ChCl} /$ urea & $\mathrm{NR}^{\mathrm{d}}$ \\
\hline 4 & $t$-BuOK (1.1) & - & 1.0 & 50 & 24 & $\mathrm{ChCl} / \mathrm{gly}$ & 24 \\
\hline 5 & $t$-BuOK (1.1) & - & 1.0 & 50 & 24 & $\mathrm{ChCl} /$ urea & 10 \\
\hline 6 & $t$-BuOK (1.1) & - & 1.0 & 50 & 24 & $\mathrm{ChCl} / \mathrm{PG}$ & 20 \\
\hline 7 & $t$-BuOK (1.1) & - & 1.0 & 100 & 24 & D-fructose/ChCl & 8 \\
\hline 8 & t-BuOK (1.1) & - & 1.0 & 100 & 24 & $\begin{array}{c}\text { D-fructose } \\
\text { /urea }\end{array}$ & 8 \\
\hline 9 & $t$-BuOK (1.1) & - & 1.0 & 50 & 24 & $\mathrm{ChCl} / \mathrm{gly}$ & 24 \\
\hline 10 & $t$-BuOK (1.1) & - & 1.0 & 50 & 24 & $\mathrm{ChCl}$ /urea & 10 \\
\hline 11 & TEA (1.4) & $\mathrm{K}_{2} \mathrm{CO}_{3}(6.6)$ & 2.3 & 50 & 24 & $\mathrm{ChCl} / \mathrm{gly}$ & $\mathrm{NR}^{\mathrm{d}}$ \\
\hline 12 & $\mathrm{~K}_{2} \mathrm{CO}_{3}(2.0)$ & - & 1.0 & 50 & 24 & $\mathrm{ChCl} / \mathrm{gly}$ & $\mathrm{NR}^{\mathrm{d}}$ \\
\hline 13 & TEA (2.0) & - & 1.0 & 50 & 24 & $\mathrm{ChCl} / \mathrm{gly}$ & 26 \\
\hline 14 & TEA (2.0) & - & 1.0 & 50 & 24 & $\mathrm{ChCl} / \mathrm{PG}$ & 44 \\
\hline 15 & TEA (2.0) & - & 2.0 & 50 & 24 & $\mathrm{ChCl} / \mathrm{PG}$ & $64^{c}$ \\
\hline 16 & TEA (2.0) & - & 2.0 & 50 & 24 & $\mathrm{ChCl} / \mathrm{gly}$ & $61^{\mathrm{c}}$ \\
\hline 17 & TEA (2.0) & - & 1.0 & 50 & 24 & DL-menthol/LA & $\mathrm{NR}^{\mathrm{d}}$ \\
\hline 18 & TEA (2.0) & - & 2.0 & 50 & 24 & $\mathrm{Bu}_{4} \mathrm{NBr} / \mathrm{gly}$ & $44^{c}$ \\
\hline 19 & TEA (2.0) & - & 2.0 & 50 & 24 & $\mathrm{Bu}_{4} \mathrm{NCl} / \mathrm{gly}$ & $68^{c}$ \\
\hline
\end{tabular}

a Reaction conditions in deep eutectic solvent (DES): $1.0 \mathrm{~g}$ DES per $0.5 \mathrm{mmol}$ of 2; DES: $\mathrm{ChCl} /$ propylene glycol (PG) $\left(1: 3, \mathrm{~mol} \mathrm{~mol}^{-1}\right)$; ChCl/gly $\left(1: 2 \mathrm{~mol} \mathrm{~mol}^{-1}\right)$; ChCl/urea $\left(1: 2 \mathrm{~mol} \mathrm{~mol}^{-1}\right)$; D-fructose/ChCl $\left(2: 1 \mathrm{~mol} \mathrm{~mol}^{-1}\right)$; D-fructose/urea (3:2 w/w); DL-menthol/L-lactic acid (LA) $\left(1: 2 \mathrm{~mol} \mathrm{~mol}^{-1}\right) ; \mathrm{Bu}_{4} \mathrm{NBr} / \mathrm{gly}\left(1: 4 \mathrm{~mol} \mathrm{~mol}^{-1}\right) ; \mathrm{Bu}_{4} \mathrm{NCl} / \mathrm{gly}$ $\left(1: 4 \mathrm{~mol} \mathrm{~mol}^{-1}\right)$. ${ }^{\mathrm{b}}$ Calculated via ${ }^{1} \mathrm{H}-\mathrm{NMR}$ analysis of the crude reaction mixture using an internal standard technique (NMR internal standard: dibromomethane). ${ }^{\mathrm{c}}$ The yields reported are for isolated products. ${ }^{\mathrm{d}} \mathrm{NR}=$ no reaction.

The deprotection of the phthalimido moiety of 3 (Figure 1, Step 3) was realized using $\mathrm{MeNH}_{2}$ ( $40 \%$ aq. solution) in place of a carcinogenic reactant such as hydrazine hydrate $[19,74]$. In this way, the $N$-benzylated adduct 4 was isolated in $95 \%$ yield. A similar yield (95\%) was observed by reacting 2 with $\mathrm{MeNH}_{2}$ in a $\mathrm{ChCl} / \mathrm{gly}(1: 2)$ eutectic mixture with $40 \mathrm{w} \%$ water. On the other hand, by alternatively using the eutectic mixture $\mathrm{ChCl} / \mathrm{PG}(1: 3)+40 \mathrm{w} \%$, adduct 4 was obtained in $45 \%$ yield only. The synthesis of 2-hydroxyphenylbenzimidazole $7 \mathbf{a}$, via a cyclodehydration reaction between 3,4-diaminobenzoic acid (5) and salicylaldehyde (6a) (Figure 1, Step 4), was also optimized in DESs using $\mathrm{Na}_{2} \mathrm{~S}_{2} \mathrm{O}_{5}$ as the oxidant (Table 2). We screened three prototypical ChCl-based eutectic mixtures whose hydrogen bond component was basic $\left(\mathrm{ChCl} / \mathrm{urea} ; 1: 2 \mathrm{~mol} \mathrm{~mol}^{-1}\right)$, neutral $(\mathrm{ChCl} / \mathrm{gly} ; 1: 2 \mathrm{~mol}$ $\left.\mathrm{mol}^{-1}\right)$ or acidic [(ChCl-L-lactic acid (LA); $\left.\left.1: 2 \mathrm{~mol} \mathrm{~mol}^{-1}\right)\right]$. All reactions were monitored through TLC analysis and stopped after complete consumption of the starting materials. As shown in Table 2, very good yields (up to $80 \%$ ) were obtained in each case in short reaction times $\left(30 \mathrm{~min}\right.$ ) at $100{ }^{\circ} \mathrm{C}$ (Table 2, entries 1-3). As for the $\mathrm{ChCl} /$ gly eutectic mixture, the percentage yield of $7 \mathbf{a}$ could be increased to up to $84 \%$ running the reaction at $50{ }^{\circ} \mathrm{C}$ (Table 2, entry 4), whereas a temperature as low as $25^{\circ} \mathrm{C}$ was detrimental even after $24 \mathrm{~h}$ reaction time ( $36 \%$ yield) (Table 2, entry 5 ). By changing the oxidant from $\mathrm{Na}_{2} \mathrm{~S}_{2} \mathrm{O}_{5}$ to the commercially available urea-hydrogen peroxide or by alternatively running the cyclodehydration reaction under air in the absence of any additional oxidant reagent, the yield of 7 a dropped down to $17 \%$ and $29 \%$ ( ${ }^{1} \mathrm{H}$ NMR analysis), respectively, the remaining being a complex mixture of unidentified products (Table 2, entries 6,7). Compound $7 \mathbf{a}$ was found to precipitate directly from the above $\mathrm{ChCl} / \mathrm{gly}$ mixture after dilution with water. Thus, it was isolated by simple filtration on 
a Büchner funnel and washing with a few drops of $\mathrm{CH}_{2} \mathrm{Cl}_{2}$. The same reaction, run in DMA at $100{ }^{\circ} \mathrm{C}$, in the presence of $\mathrm{Na}_{2} \mathrm{~S}_{2} \mathrm{O}_{5}$, provided $7 \mathrm{a}$ in $67 \%$ yield only after $12 \mathrm{~h}$ reaction time (Table 2, entry 8).

Table 2. Optimization of the synthesis of 2-hydroxyphenylbenzimidazole 7a. ${ }^{\text {a }}$

\begin{tabular}{|c|c|c|c|c|c|}
\hline & & & & & $7 a$ \\
\hline Entry & $\mathrm{T}\left({ }^{\circ} \mathrm{C}\right)$ & $T(h)$ & Oxidant & Solvent & $7 a$, Yield $(\%)^{b}$ \\
\hline 1 & 100 & 0.5 & $\mathrm{Na}_{2} \mathrm{~S}_{2} \mathrm{O}_{5}$ & $\mathrm{ChCl} /$ urea & 66 \\
\hline 2 & 100 & 0.5 & $\mathrm{Na}_{2} \mathrm{~S}_{2} \mathrm{O}_{5}$ & $\mathrm{ChCl} / \mathrm{gly}$ & 80 \\
\hline 3 & 100 & 0.5 & $\mathrm{Na}_{2} \mathrm{~S}_{2} \mathrm{O}_{5}$ & $\mathrm{ChCl} / \mathrm{LA}$ & 76 \\
\hline 4 & 50 & 0.5 & $\mathrm{Na}_{2} \mathrm{~S}_{2} \mathrm{O}_{5}$ & $\mathrm{ChCl} / \mathrm{gly}$ & 84 \\
\hline 5 & 25 & 24 & $\mathrm{Na}_{2} \mathrm{~S}_{2} \mathrm{O}_{5}$ & $\mathrm{ChCl} / \mathrm{gly}$ & 36 \\
\hline 6 & 50 & 0.5 & urea- $\mathrm{H}_{2} \mathrm{O}_{2}$ & $\mathrm{ChCl} / \mathrm{gly}$ & $17^{\mathrm{c}}$ \\
\hline 7 & 50 & 0.5 & $-d$ & $\mathrm{ChCl} / \mathrm{gly}$ & $29^{c}$ \\
\hline 8 & 100 & 12 & $\mathrm{Na}_{2} \mathrm{~S}_{2} \mathrm{O}_{5}$ & DMA & 67 \\
\hline
\end{tabular}

a Reaction conditions in DES: $1.0 \mathrm{~g}$ DES per $0.5 \mathrm{mmol}$ of $\mathbf{5}, 0.5 \mathrm{mmol}$ of $\mathbf{6 a}$ and $0.7 \mathrm{mmol}$ of oxidant; DES: $\mathrm{ChCl} / \mathrm{gly}$ $\left(1: 2 \mathrm{~mol} \mathrm{~mol}^{-1}\right) ; \mathrm{ChCl} /$ urea $\left(1: 2 \mathrm{~mol} \mathrm{~mol}^{-1}\right) ; \mathrm{ChCl} / \mathrm{LA}\left(1: 2 \mathrm{~mol} \mathrm{~mol}^{-1}\right) ;{ }^{\mathrm{b}}$ The yields reported are for isolated products. ${ }^{c}$ Calculated via ${ }^{1} \mathrm{H}-\mathrm{NMR}$ analysis of the crude reaction mixture using an internal standard technique (NMR internal standard: dibromomethane). ${ }^{\mathrm{d}}$ Under air.

Possibly looking forward to developing and testing novel donepezil-hybrids, we decided to broaden already at this stage the scope of the aforementioned cyclodehydration reaction using $\mathrm{ChCl} / \mathrm{gly}$ as a privileged reaction medium. The functionalization of the phenolic acid component may indeed contribute to modify the biological properties of the corresponding adducts, thereby tuning their chelating properties for the treatment of AD. In line with this strategy, Liang et al. recently synthesized a series of novel halogenated 8-hydroxyquinolines as derivatives of Clioquinol (CQ), which is a well-known prototypical metal-chelating drug [68]. CQ was studied up to phase II clinical trial with promising results, but it was later discontinued because of issues encountered during the development of the industrial production process [2,75]. In particular, it was noticed that the introduction in the CQ structure of powerful electron-withdrawing groups led to an improved metal-chelating activity [68]. Another research group recently explored also the potentiality of these substituted nuclei as antioxidant agents [76]. To our delight, by reacting a variety of salicylaldehyde derivatives $\mathbf{6 b}-\mathbf{h}$, decorated with electron-donating and electron-withdrawing substituents, with $\mathbf{5}$, the desired 2-hydroxyphenylbenzimidazole derivatives $\mathbf{7 b}-\mathbf{h}$ could be smoothly synthesized in $72-97 \%$ yield within $30 \mathrm{~min}$ reaction tim at $50{ }^{\circ} \mathrm{C}$ (Figure 2). Of note, using DMA as the reaction medium, the above adducts have been reported to be prepared in 51-74\% yield after $12 \mathrm{~h}$ reaction time at $100{ }^{\circ} \mathrm{C}$ [77]. The synthesis of 1,2-disubstituted or 2-substituted benzimidazoles has also been recently achieved using o-phenylenediamine (o-PDA) both as a component of the eutectic mixture $\mathrm{ChCl} / o-\mathrm{PDA}(1: 1 \mathrm{~mol}$ $\mathrm{mol}^{-1}$ ) and as a reagent in combination with different aldehydes [78]. 


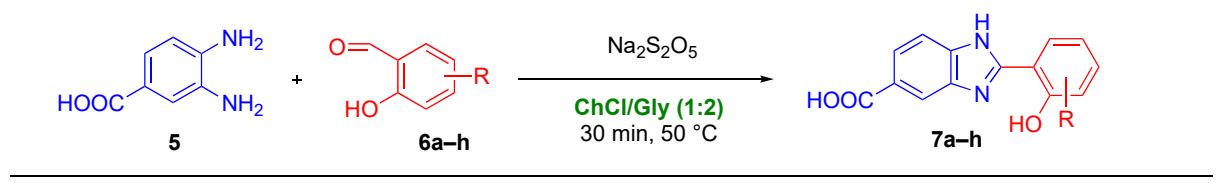<smiles>O=C(O)c1ccc2[nH]c(-c3ccccc3O)nc2c1</smiles><smiles>O=C(O)c1ccc2[nH]c(-c3cc(Br)ccc3O)nc2c1</smiles><smiles>O=C(O)c1ccc2[nH]c(-c3cc(F)ccc3O)nc2c1</smiles><smiles>O=C(O)c1ccc2[nH]c(-c3cc(Cl)ccc3O)nc2c1</smiles><smiles>O=C(O)c1ccc2[nH]c(-c3cc([N+](=O)[O-])ccc3O)nc2c1</smiles><smiles>COc1ccc(O)c(-c2nc3cc(C(=O)O)ccc3[nH]2)c1</smiles><smiles>COc1ccc(-c2nc3cc(C(=O)O)ccc3[nH]2)c(O)c1</smiles><smiles>O=C(O)c1ccc2[nH]c(-c3ccc(O)cc3O)nc2c1</smiles>

Figure 2. Scope of the cyclodehydration reaction for the synthesis of 2-hydroxyphenylbenzimidazole derivatives 7. Yields refer to isolated products.

Finally, the one-pot two-step synthesis of PZ1 (8) in DESs (Figure 1, Step 5) was investigated by reacting the $N$-benzylated adduct 4 (Figure 1, Step 3) with 2-hydroxyphenylbenzimidazole derivative 7a (Figure 1, Step 4) (Table 3). The preparation of PZ1 from 4 and 7a has only been performed to date in DMF, working at $25{ }^{\circ} \mathrm{C}$ for $60 \mathrm{~h}$, with the product isolated in $21 \%$ yield (Table 3 , entry 1 ). The use of $\mathrm{ChCl} / \mathrm{PG}$ (1:3) as the solvent proved to be better with respect to other hydrophilic and hydrophobic eutectic mixtures as it provided PZ1 in an overall $30 \%$ yield at $60{ }^{\circ} \mathrm{C}$ after $60 \mathrm{~h}$ reaction time (Table 3 , entries 2-8). The presence of both $N, N^{\prime}$-dicyclohexylcarbodiimide (DCC) and $N$-hydroxysuccinimide (NHS) was also essential for the in situ formation of the amide moiety of 8 (Table 3, entries 9,10).

Table 3. Optimization of the synthesis of PZ1 (8). ${ }^{\text {a }}$

\begin{tabular}{|c|c|c|c|c|c|}
\hline Entry & Reagent 1 (Equiv) & Reagent 2 (Equiv) & $\mathrm{T}\left({ }^{\circ} \mathrm{C}\right)$ & Solvent & 8 , Yield $(\%)^{b}$ \\
\hline 1 & NHS (1) & DCC (1) & 25 & DMF & 21 \\
\hline 2 & NHS (1) & DCC (1) & 60 & ChCl/gly & 16 \\
\hline 3 & NHS (1) & DCC (1) & 60 & $\mathrm{ChCl} / \mathrm{PG}$ & 30 \\
\hline 4 & NHS (1) & DCC (1) & 60 & $\mathrm{ChCl} /$ urea & 13 \\
\hline 5 & NHS (1) & DCC (1) & 60 & menthol/LA & $\mathrm{NR}^{\mathrm{c}}$ \\
\hline 6 & NHS (1) & $\operatorname{DCC}(1)$ & 60 & D-fructose/urea & $\mathrm{NR}^{\mathrm{c}}$ \\
\hline 7 & NHS (1) & $\operatorname{DCC}(1)$ & 60 & $\mathrm{Bu}_{4} \mathrm{NBr} / \mathrm{gly}$ & $7^{d}$ \\
\hline 8 & NHS (1) & DCC (1) & 60 & $\mathrm{Bu}_{4} \mathrm{NCl} / \mathrm{gly}$ & $19^{\mathrm{d}}$ \\
\hline 9 & NHS (1) & - & 60 & $\mathrm{ChCl} / \mathrm{PG}$ & $<5^{d}$ \\
\hline 10 & - & DCC (1) & 60 & $\mathrm{ChCl} / \mathrm{PG}$ & $\mathrm{NR}^{\mathrm{c}}$ \\
\hline
\end{tabular}

a Reaction conditions in DES: $1.0 \mathrm{~g}$ DES per $0.5 \mathrm{mmol}$ of 4; DES: ChCl/gly $\left(1: 2 \mathrm{~mol} \mathrm{~mol}^{-1}\right)$; $\mathrm{ChCl} / \mathrm{urea}(1: 2 \mathrm{~mol}$ $\left.\mathrm{mol}^{-1}\right)$; ChCl/PG (1:3 $\left.\mathrm{mol} \mathrm{mol}^{-1}\right)$; D-fructose/urea (3:2 w/w); DL-menthol/LA $\left(1: 2 \mathrm{~mol} \mathrm{~mol}^{-1}\right) ; \mathrm{Bu}_{4} \mathrm{NBr} / \mathrm{gly}(1: 4 \mathrm{~mol}$ $\left.\mathrm{mol}^{-1}\right) ; \mathrm{Bu}_{4} \mathrm{NCl} / \mathrm{gly}\left(1: 4 \mathrm{~mol} \mathrm{~mol}^{-1}\right) .{ }^{\mathrm{b}}$ The yields reported are for isolated products. ${ }^{\mathrm{c}}$ No reaction. ${ }^{\mathrm{d}}$ Calculated via ${ }^{1} \mathrm{H}-\mathrm{NMR}$ analysis of the crude reaction mixture using an internal standard technique (NMR internal standard: dibromomethane). 


\section{Materials and Methods}

\subsection{General Methods}

${ }^{1} \mathrm{H}$ NMR and ${ }^{13} \mathrm{C}$ NMR spectra were recorded on a Bruker $600 \mathrm{MHz}$ spectrometer and chemical shifts are reported in parts per million $(\delta)$. FT-IR spectra were recorded on a Perkin-Elmer 681 spectrometer. GC analyses were performed on a HP 6890 model, Series II by using a HP1 column (methyl siloxane; $30 \mathrm{~m}, 0.32 \mathrm{~mm}, 0.25 \mu \mathrm{m}$ film thickness). Analytical thin-layer chromatography (TLC) was carried out on pre-coated $0.25 \mathrm{~mm}$ thick plates of Kieselgel $60 \mathrm{~F}_{254}$; visualization was accomplished by UV light (254 $\mathrm{nm}$ ) or by spraying a solution of $5 \%(w / v)$ ammonium molybdate and $0.2 \%(w / v)$ cerium(III) sulfate in $100 \mathrm{~mL} 17.6 \%(w / v)$ aq. sulfuric acid and heating to $473 \mathrm{~K}$ until blue spots appeared. Chromatography was conducted by using silica gel 60 with a particle size distribution 40-63 $\mu \mathrm{m}$ and 230-400 ASTM. GC-MS analyses were performed on HP 5995C model. High-resolution mass spectrometry (HRMS) analyses were performed using a Bruker microTOF QII mass spectrometer equipped with an electrospray ion source (ESI). Reagents and solvents, unless otherwise specified, were purchased from Sigma-Aldrich (Sigma-Aldrich, St. Louis, MO, USA) and used without any further purification.

\subsection{Preparation of Deep Eutectic Solvents (DESs)}

DESs [choline chloride (ChCl)/propylene glycol (PG) $\left(1: 3 \mathrm{~mol} \mathrm{~mol}^{-1}\right)$; ChCl/L-lactic acid (LA) (1:2 mol mol $\left.{ }^{-1}\right) ;$ D-fructose/urea $(3: 2 w / w) ; ~ D-f r u c t o s e / C h C l ~\left(2: 1 \mathrm{~mol} \mathrm{~mol}^{-1}\right) ; \mathrm{ChCl} /$ urea $\left(1: 2 \mathrm{~mol} \mathrm{~mol}^{-1}\right)$; $\mathrm{ChCl} /$ glycerol (gly) (1:2 mol mol ${ }^{-1}$; DL-menthol/LA (1:2 mol mol $\left.{ }^{-1}\right) ; \mathrm{Bu}_{4} \mathrm{NBr} / \mathrm{gly}\left(1: 4 \mathrm{~mol} \mathrm{~mol}^{-1}\right)$; $\mathrm{Bu}_{4} \mathrm{NCl} / \mathrm{gly}\left(1: 4 \mathrm{~mol} \mathrm{~mol}^{-1}\right)$ ] were prepared by heating under stirring at $60-80^{\circ} \mathrm{C}$ for $10-30 \mathrm{~min}$ the corresponding individual components until a clear solution was obtained.

\subsection{Synthesis and Characterization Data of 2-[2-(4-benzylpiperazin-1-yl)ethyl]isoindoline-1,3-dione (2)}

Phthalic acid anhydride (0.5 mmol) and 1-(2-aminoethyl)piperazine 1 (0.5 mmol) were heated at $180{ }^{\circ} \mathrm{C}$ for $5 \mathrm{~h}$ to give 2-[2-(piperazin-1-yl)ethyl]isoindoline-1,3-dione (2) as a dark brown solid in $>98 \%$ yield ( ${ }^{1} \mathrm{H}$ NMR analysis) $[19,70]$.

Table 1, entry 1: the resulting dark brown solid (2), $(0.5 \mathrm{mmol})$ was mixed with $\mathrm{K}_{2} \mathrm{CO}_{3}(3.3 \mathrm{mmol})$, triethylamine (TEA) $(1.0 \mathrm{mmol})$ and benzyl bromide $(1.15 \mathrm{mmol})$ and refluxed in acetonitrile $(2 \mathrm{~mL})$ for $3 \mathrm{~h}$ at $50{ }^{\circ} \mathrm{C}$. Then, the mixture was cooled to room temperature and $5 \mathrm{~mL}$ of $\mathrm{H}_{2} \mathrm{O}$ were added. The resulting aqueous suspension was then extracted with AcOEt $(3 \times 10 \mathrm{~mL})$. The combined organic phase were dried over anhydrous $\mathrm{Na}_{2} \mathrm{SO}_{4}$ and concentrated under reduced pressure. The crude product was purified by flash-chromatography (silica gel; eluent: $\mathrm{CH}_{2} \mathrm{Cl}_{2} / \mathrm{MeOH} / \mathrm{TEA}$ 98:2:0.1) to give 3 as a yellow solid (64\% yield).

Table 1, entry 19: the resulting dark brown solid (2), (0.5 mmol), TEA (1.0 mmol) and benzyl bromide $(1.0 \mathrm{mmol})$ were dissolved in the $\mathrm{Bu}_{4} \mathrm{NCl} / \mathrm{gly}$ eutectic mixture $(1.0 \mathrm{~g})$ under magnetic stirring, and the resulting mixture was then heated at $50{ }^{\circ} \mathrm{C}$ for $24 \mathrm{~h}$. After this time, the reaction mixture was cooled to room temperature and $5 \mathrm{~mL}$ of $\mathrm{H}_{2} \mathrm{O}$ were added. The resulting aqueous suspension was then extracted with AcOEt $(3 \times 10 \mathrm{~mL})$. The combined organic phases were washed with brine $(10 \mathrm{~mL})$, dried over anhydrous $\mathrm{Na}_{2} \mathrm{SO}_{4}$ and concentrated under reduced pressure. The crude product was purified by flash-chromatography (silica gel; eluent: $\mathrm{CH}_{2} \mathrm{Cl}_{2} / \mathrm{MeOH} / \mathrm{TEA}$ 98:2:0.1) to give 3 as a yellow solid (68\% yield).

2-[2-(4-benzylpiperazin-1-yl)ethyl]isoindoline-1,3-dione (3). ${ }^{1} \mathrm{H} \mathrm{NMR}\left(400 \mathrm{MHz}, \mathrm{CDCl}_{3}\right), \delta$ (ppm): $2.39-2.52$ (m, $8 \mathrm{H}$, piperazine), $2.60\left(\mathrm{t}, 2 \mathrm{H}, \mathrm{J}=6.7 \mathrm{~Hz}\right.$, phthalimide- $\left.\mathrm{CH}_{2} \mathrm{CH}_{2} \mathrm{~N}\right), 3.44\left(\mathrm{~s}, 2 \mathrm{H}, \mathrm{NCH}_{2} \mathrm{Ph}\right), 3.78(\mathrm{t}, 2$ $\mathrm{H}, \mathrm{J}=6.7 \mathrm{~Hz}$, phthalimide- $\left.\mathrm{CH}_{2} \mathrm{CH}_{2} \mathrm{~N}\right), 7.19-7.27\left(\mathrm{~m}, 5 \mathrm{H}\right.$, aromatics, $\left.\mathrm{Ph}-\mathrm{CH}_{2}\right), 7.67-7.69$ and 7.80-7.82 (m, $4 \mathrm{H}$, phthalimide). ${ }^{13} \mathrm{C} \mathrm{NMR}\left(150 \mathrm{MHz}, \mathrm{CDCl}_{3}\right) \delta$ (ppm): 35.3, 53.0, 53.1, 55.7, 63.0, 123.2, 127.0, $128.2,129.2,132.2,133.8,138.1,168.3$. GC-MS (m/z): $349\left(\mathrm{M}^{+}, 7\right), 189(100), 91(47)$. HRMS [M + H] ${ }^{+}$: calculated 350.1863; found 350.1858. 


\subsection{Synthesis and Characterization Data of 2-(4-benzyl-1-piperazinyl)ethanamine (4)}

Compound $3(1.0 \mathrm{mmol})$ was dissolved in an aq. solution of $\mathrm{MeNH}_{2}(40 \% w / w, 3.0 \mathrm{~mL})$ under magnetic stirring for $24 \mathrm{~h}$ at room temperature. After this time, an aq. solution of $\mathrm{NaOH}(20 \% w / w$, $3.0 \mathrm{~mL})$ was added. After $2 \mathrm{~h}, \mathrm{NaCl}(0.3 \mathrm{~g})$ was added, and the resulting solution was extracted with AcOEt $(3 \times 10 \mathrm{~mL})$. The combined organic phases were washed with brine $(10 \mathrm{~mL})$, dried over anhydrous $\mathrm{Na}_{2} \mathrm{SO}_{4}$ and concentrated under reduced pressure to give 4 as a yellow oil (95\% yield).

${ }^{1} \mathrm{H}$ NMR (400 MHz, $\mathrm{CDCl}_{3}$ ), $\delta$ (ppm): 2.35-2.43 (m, $10 \mathrm{H}$, piperazine, $\left.\mathrm{NH}_{2}-\mathrm{CH}_{2} \mathrm{CH}_{2} \mathrm{~N}\right), 2.73(\mathrm{t}, 2 \mathrm{H}, J=$ $\left.6.1 \mathrm{~Hz}, \mathrm{NH}_{2}-\mathrm{CH}_{2} \mathrm{CH}_{2} \mathrm{~N}\right), 3.46\left(\mathrm{~s}, 2 \mathrm{H}, \mathrm{NCH}_{2} \mathrm{Ph}\right), 7.18-7.27\left(\mathrm{~m}, 5 \mathrm{H}\right.$, aromatics, $\left.\mathrm{Ph}-\mathrm{CH}_{2}\right) .{ }^{13} \mathrm{C} \mathrm{NMR}$ $\left(150 \mathrm{MHz}, \mathrm{CDCl}_{3}\right) \delta$ (ppm): 38.7, 53.1, 53.2, 61.1, 63.1, 127.0, 128.2, 129.2, 138.0. GC-MS (m/z): $219\left(\mathrm{M}^{+}\right.$, 1), 189 (100), 91 (94). HRMS [M + H] ${ }^{+}$: calculated 220.1808; found 220.1809.

\subsection{Synthesis and Characterization Data of 2-(2-hydroxyphenyl)-1H-benzo[d]imidazole-5-carboxylic Acid (7a)}

Table 2, entry 8: to a solution of salicylaldehyde $(0.5 \mathrm{mmol})$ in $N, N$-dimethylacetamide $(2 \mathrm{~mL})$, 3,4-diaminobenzoic acid $(0.5 \mathrm{mmol})$ and $\mathrm{Na}_{2} \mathrm{~S}_{2} \mathrm{O}_{5}(0.7 \mathrm{mmol})$ were progressively added under magnetic stirring. The resulting mixture was heated at $100{ }^{\circ} \mathrm{C}$ for $12 \mathrm{~h}$, and then cooled to room temperature. The mixture was finally diluted with AcOEt $(10 \mathrm{~mL})$, washed with brine $(3 \times 10 \mathrm{~mL})$, dried over anhydrous $\mathrm{Na}_{2} \mathrm{SO}_{4}$ and concentrated under reduced pressure to give $7 \mathbf{a}$ as a pale brown solid (67\% yield).

Table 2, entry 4: 3,4-diaminobenzoic acid ( $0.5 \mathrm{mmol})$, salicylaldehyde $(0.5 \mathrm{mmol})$ and $\mathrm{Na}_{2} \mathrm{~S}_{2} \mathrm{O}_{5}$ $(0.7 \mathrm{mmol})$ were progressively dissolved in a $\mathrm{ChCl} / \mathrm{gly}$ eutectic mixture $(1.0 \mathrm{~g})$, and the resulting mixture was warmed at $50{ }^{\circ} \mathrm{C}$ for $30 \mathrm{~min}$. After this time, the reaction mixture was cooled to room temperature and $10 \mathrm{~mL}$ of $\mathrm{H}_{2} \mathrm{O}$ were added. This caused the precipitation of $7 \mathbf{a}$ as a pale brown solid, which was isolated by filtration on a Büchner funnel and washing with a few drops of $\mathrm{CH}_{2} \mathrm{Cl}_{2}$ (84\% yield).

2-(2-Hydroxyphenyl)-1H-benzo[d]imidazole-5-carboxylic acid (7a) ${ }^{1} \mathrm{H}$ NMR (400 MHz, DMSO-d 6 ) $\delta(\mathrm{ppm})$ : 7.02-7.08 (m, $2 \mathrm{H}), 7.41(\mathrm{t}, J=7.4 \mathrm{~Hz}, 1 \mathrm{H}), 7.73(\mathrm{~d}, J=7.7 \mathrm{~Hz}, 1 \mathrm{H}), 7.91(\mathrm{~d}, J=7.9 \mathrm{~Hz}, 1 \mathrm{H}), 8.11$ $(\mathrm{d}, J=8.1 \mathrm{~Hz}, 1 \mathrm{H}), 8.24(\mathrm{~s}, 1 \mathrm{H}) .{ }^{13} \mathrm{C}$ NMR $\left(100 \mathrm{MHz}, \mathrm{DMSO}-\mathrm{d}_{6}\right) \delta(\mathrm{ppm}): 168.1,158.5,132.7,127.2$, 125.7, 124.55, 119.7, 117.7, 112.9. ESI-MS (m/z): $253(\mathrm{M}-1), 255(\mathrm{M}+1)$. HRMS [(M - H] $]^{-}$: calculated 253.0619; found 253.0637.

\subsection{Synthesis and Characterization Data of 2-(2-hydroxyphenyl)-1H-benzo[d]imidazole-5-carboxylic Acid Derivatives $(\mathbf{7 b}-\boldsymbol{h})$}

Compounds $\mathbf{7 b}-\mathbf{h}$ were synthesized in the $\mathrm{ChCl} /$ gly eutectic mixture according to the procedure described for $7 \mathbf{a}$ in Section 3.5.

2-(5-Bromo-2-hydroxyphenyl)-1H-benzo[d]imidazole-5-carboxylic acid (7b). White solid, m.p. $>300{ }^{\circ} \mathrm{C}$, 72\% yield. ${ }^{1} \mathrm{H}$ NMR $\left(600 \mathrm{MHz}, \mathrm{DMSO}_{6}\right) \delta(\mathrm{ppm}): 7.05(\mathrm{~d}, J=8.7 \mathrm{~Hz}, 1 \mathrm{H}, \mathrm{BIM}-\mathrm{H}-4), 7.55(\mathrm{~d}, J=8.7$ $\mathrm{Hz}, 1 \mathrm{H}, \mathrm{BIM}-\mathrm{H}-5), 7.74$ (d, J = 8.3 Hz, $1 \mathrm{H}, \mathrm{BIM}-\mathrm{H}-2), 7.91$ (d, J = 8.3 Hz, $1 \mathrm{H}, \mathrm{BIM}-\mathrm{H}-3), 8.24$ (s, $1 \mathrm{H}$, BIM-H-7), 8.30 (s, 1 H, BIM-H-1), 12.95 (broad s, 1 H, COOH). ${ }^{13} \mathrm{C}$ NMR $\left(150 \mathrm{MHz}, \mathrm{DMSO}-\mathrm{d}_{6}\right) \delta(\mathrm{ppm})$ : $110.8,114.9,115.0,120.0,124.8,124.9,126.0,129.5,135.1,152.4,152.5,157.5,168.0$. HRMS [M - H] ${ }^{-}$: calculated 330.9724; found 330.9722.

2-(5-Fluoro-2-hydroxyphenyl)-1H-benzo[d]imidazole-5-carboxylic acid (7c). White solid, m.p. $250{ }^{\circ} \mathrm{C}, 97 \%$ yield. ${ }^{1} \mathrm{H}$ NMR $\left(600 \mathrm{MHz}, \mathrm{DMSO}-\mathrm{d}_{6}\right) \delta(\mathrm{ppm})$ : 7.04-7.06 (m, $\left.1 \mathrm{H}\right), 7.22-7.25(\mathrm{~m}, 1 \mathrm{H}), 7.70-7.72(\mathrm{~m}$, $1 \mathrm{H}), 7.88-7.90(\mathrm{~m}, 2 \mathrm{H}), 7.98-8.01(\mathrm{~m}, 1 \mathrm{H}), 8.25$ (broad s, $1 \mathrm{H}), 12.78($ broad s, $1 \mathrm{H}) .{ }^{13} \mathrm{C}$ NMR $(150$ MHz, DMSO- $\left.\mathrm{d}_{6}\right) \delta(\mathrm{ppm}): 112.8\left(\mathrm{~d},{ }^{2} J_{\mathrm{C}-\mathrm{F}}=25.0 \mathrm{~Hz}\right), 113.3\left(\mathrm{~d},{ }^{3} J_{\mathrm{C}-\mathrm{F}}=8.1 \mathrm{~Hz}\right), 119.0\left(\mathrm{~d},{ }^{3} J_{\mathrm{C}-\mathrm{F}}=7.8\right.$ $\mathrm{Hz}), 119.4\left({ }^{2} J_{\mathrm{C}-\mathrm{F}}=23.3 \mathrm{~Hz}\right), 124.6,124.7,125.9,153.0,153.2,154.6,155.5\left(\mathrm{~d},{ }^{2} J_{\mathrm{C}-\mathrm{F}}=234.5 \mathrm{~Hz}\right), 168.1$. HRMS [M - H] $]^{-}$: calculated 271.0524; found 271.0525. 
2-(5-Chloro-2-hydroxyphenyl)-1H-benzo[d]imidazole-5-carboxylic acid (7d). White solid, m.p. $>300{ }^{\circ} \mathrm{C}$, 72\% yield. ${ }^{1} \mathrm{H}$ NMR (300 MHz, DMSO-d 6 ), $\delta(\mathrm{ppm}): 7.10(\mathrm{~d}, 1 \mathrm{H}, J=6.0 \mathrm{~Hz}), 7.44(\mathrm{~d}, 1 \mathrm{H}, J=6.0$ $\mathrm{Hz}), 7.73-7.75(\mathrm{~m}, 1 \mathrm{H}), 7.90(\mathrm{~d}, 1 \mathrm{H}, J=6.0 \mathrm{~Hz}), 8.19(\mathrm{~s}, 1 \mathrm{H}), 8.24$ (broad s, $1 \mathrm{H}), 12.86$ (broad s, $1 \mathrm{H}$, $\mathrm{COOH}) .{ }^{13} \mathrm{C}$ NMR $\left(150 \mathrm{MHz}, \mathrm{DMSO}-\mathrm{d}_{6}\right) \delta$ (ppm): 119.6, 123.4, 124.8, 125.9, 126.5, 132.2, 152.7, 157.1, 168.0. HRMS [M - H] $]^{-}$: calculated 287.0229; found 287.0228.

2-(5-Nitro-2-hydroxyphenyl)-1H-benzo[d]imidazole-5-carboxylic acid (7e). White solid, m.p. $>300{ }^{\circ} \mathrm{C}, 78 \%$ yield. ${ }^{1} \mathrm{H}$ NMR (600 MHz, DMSO-d 6 ) $\delta(\mathrm{ppm}):$ 7.06-7.11 (m, $\left.1 \mathrm{H}\right), 7.25-7.32(\mathrm{~m}, 1 \mathrm{H}), 7.73-7.76(\mathrm{~m}$, $1 \mathrm{H}), 7.89-7.96$ (m, $2 \mathrm{H}), 8.24$ (broad s, $1 \mathrm{H}), 12.78$ (broad s, $1 \mathrm{H}) .{ }^{13} \mathrm{C}$ NMR $\left(150 \mathrm{MHz}, \mathrm{DMSO}-\mathrm{d}_{6}\right) \delta$ (ppm): 113.3, 114.4, 118.9, 122.1, 123.4, 126.9, 127.5, 128.1, 129.1, 129.5, 152.7, 169.2. HRMS [M - H] ${ }^{-}$: calculated 298.0469; found 298.0468.

2-(4-Methoxy-2-hydroxyphenyl)-1H-benzo[d]imidazole-5-carboxylic acid (7f). White solid, m.p. $>300{ }^{\circ} \mathrm{C}$, $67 \%$ yield. ${ }^{1} \mathrm{H}$ NMR $\left(600 \mathrm{MHz}, \mathrm{DMSO}-\mathrm{d}_{6}\right), \delta(\mathrm{ppm}): 3.79(\mathrm{~s}, 3 \mathrm{H}), 6.59-6.63(\mathrm{~m}, 2 \mathrm{H}) 7.66(\mathrm{~d}, J=9.0 \mathrm{~Hz}$, $1 \mathrm{H}), 7.86(\mathrm{~d}, J=9.0 \mathrm{~Hz}, 1 \mathrm{H}), 8.10(\mathrm{~d}, J=9.0 \mathrm{~Hz}, 1 \mathrm{H}), 8.18(\mathrm{~s}, 1 \mathrm{H}), 12.96$ (broad s, $1 \mathrm{H}) .{ }^{13} \mathrm{C}$ NMR $(150$ MHz, DMSO-d 6 ) $\delta$ (ppm): 55.9, 101.9, 105.8, 107.2, 124.4, 125.3, 128.6, 154.4, 160.4, 163.1, 168.1. HRMS $[\mathrm{M}-\mathrm{H}]^{-}$: calculated 283.0724; found 283.0728.

2-(5-Methoxy-2-hydroxyphenyl)-1H-benzo[d]imidazole-5-carboxylic acid (7g). White solid, m.p. $>300{ }^{\circ} \mathrm{C}$, 79\% yield. ${ }^{1} \mathrm{H}$ NMR (600 MHz, DMSO-d 6 ), $\delta(\mathrm{ppm}): 3.33(\mathrm{~s}, 3 \mathrm{H}), 6.64(\mathrm{~d}, J=9.0 \mathrm{~Hz}, 1 \mathrm{H}), 6.74(\mathrm{~d}, J=$ $9.0 \mathrm{~Hz}, 1 \mathrm{H}), 7.19$ (s, $1 \mathrm{H}), 7.90-7.92(\mathrm{~m}, 1 \mathrm{H}), 8.09-8.11(\mathrm{~m}, 1 \mathrm{H}), 8.27$ (s, $1 \mathrm{H}), 10.2$ (broad s, $1 \mathrm{H}) .{ }^{13} \mathrm{C}$ NMR (150 MHz, DMSO-d 6 ) $\delta$ (ppm): 56.2, 110.7, 112.7, 118.6, 119.8, 124.3, 125.7, 150.2, 152.5, 154.1, 168.1. HRMS [M - H] $]^{-}$: calculated 283.0724; found 283.0725.

2-(2,4-Dihydroxyphenyl)-1H-benzo[d]imidazole-5-carboxylic acid (7h). White solid, m.p. $>300{ }^{\circ} \mathrm{C}, 94 \%$ yield. ${ }^{1} \mathrm{H}$ NMR (300 MHz, DMSO-d 6 ), $\delta(\mathrm{ppm}): 6.43(\mathrm{~s}, 1 \mathrm{H}) 6.47(\mathrm{~d}, J=6.0 \mathrm{~Hz}, 1 \mathrm{H}), 7.65(\mathrm{~d}, J=6.0 \mathrm{~Hz}$, $1 \mathrm{H}), 7.86(\mathrm{~d}, J=9.0 \mathrm{~Hz}, 1 \mathrm{H}), 7.89(\mathrm{~d}, J=9.0 \mathrm{~Hz}, 1 \mathrm{H}), 8.15(\mathrm{~s}, 1 \mathrm{H}), 12.96$ (broad s, $1 \mathrm{H}) .{ }^{13} \mathrm{C}$ NMR $(150$ MHz, DMSO-d 6 ) $\delta$ (ppm): 103.5, 104.7, 108.3, 113.1, 113.2, 115.8, 120.8, 125.2, 128.4, 140.5, 155.9, 160.4, 161.7, 168.5. HRMS [M - H] $]^{-}$: calculated 269.0568; found 269.0564.

3.7. Synthesis and Characterization Data of N-(2-(4-benzylpiperazin-1-yl)ethyl)-2-(2-hydroxy-phenyl)-1H-benzo[d]imidazole-5-carboxamide (PZ1) (8)

Table 3, entry 1: a mixture of $4(0.5 \mathrm{mmol}), 7 \mathrm{a}(0.5 \mathrm{mmol}), N$-hydroxysuccinimide $(0.5 \mathrm{mmol})$ and $N, N^{\prime}$-dicyclohexylcarbodiimide $(0.5 \mathrm{mmol})$ in anhydrous DMF $(3 \mathrm{~mL})$ was stirred at room temperature for $60 \mathrm{~h}$ under a nitrogen atmosphere. After this time, the resulting mixture was filtered on a Büchner funnel, diluted with AcOEt $(10 \mathrm{~mL})$, and washed with brine $(10 \mathrm{~mL})$. The organic phase was dried over anhydrous $\mathrm{Na}_{2} \mathrm{SO}_{4}$ and concentrated under reduced pressure. The crude product was purified by flash-chromatography (silica gel; eluent: $\mathrm{CH}_{2} \mathrm{Cl}_{2} / \mathrm{MeOH}$ 98:2:) to give 8 as a yellow solid (21\% yield).

Table 3, entry 3: compounds $4(0.5 \mathrm{mmol}), 7 \mathrm{a}(0.5 \mathrm{mmol}), N$-hydroxysuccinimide $(0.5 \mathrm{mmol})$ and $N, N^{\prime}$-dicyclohexylcarbodiimide $(0.5 \mathrm{mmol})$ were progressively dissolved in a $\mathrm{ChCl} / \mathrm{PG}$ eutectic mixture $(1.0 \mathrm{~g})$ under magnetic stirring, and the resulting mixture was then heated at $60{ }^{\circ} \mathrm{C}$ for $60 \mathrm{~h}$. After this time, the reaction mixture was cooled to room temperature and $5 \mathrm{~mL}$ of $\mathrm{H}_{2} \mathrm{O}$ were added. The resulting aqueous suspension was then extracted with AcOEt $(3 \times 10 \mathrm{~mL})$. The combined organic phases were washed with brine $(10 \mathrm{~mL})$, dried over anhydrous $\mathrm{Na}_{2} \mathrm{SO}_{4}$ and concentrated under reduced pressure. The crude product was purified by flash-chromatography (silica gel; eluent: AcOEt/MeOH 98:2) to give 8 as a yellow solid (30\% yield).

N-(2-(4-Benzylpiperazin-1-yl)ethyl)-2-(2-hydroxy-phenyl)-1H-benzo[d]imidazole-5-carboxamide (PZ1) (8). Yellow solid, m.p.= 249-252 ${ }^{\circ} \mathrm{C} .{ }^{1} \mathrm{H}$ NMR $\left(400 \mathrm{MHz}, \mathrm{DMSO}-\mathrm{d}_{6}\right), \delta$ (ppm): 2.34-2.47 (m, 10 H, 8 piperazine and $\left.2 \mathrm{NH}_{2}-\mathrm{CH}_{2} \mathrm{CH}_{2} \mathrm{~N}\right), 3.36-3.41\left(\mathrm{~m}, 4 \mathrm{H}, 2 \mathrm{NCH}_{2} \mathrm{Ph}\right.$ and $\left.2 \mathrm{NH}_{2}-\mathrm{CH}_{2} \mathrm{CH}_{2} \mathrm{~N}\right), 6.99-7.09$ $(\mathrm{m}, 2 \mathrm{H}), 7.19-7.34(\mathrm{~m}, 4 \mathrm{H}), 7.39-7.44(\mathrm{~m}, 1 \mathrm{H}), 7.65-7.72(\mathrm{~m}, 1 \mathrm{H}), 7.76-7.83(\mathrm{~m}, 1 \mathrm{H}), 8.05-7.11(\mathrm{~m}, 1$ $\mathrm{H}), 8.13-8.15(\mathrm{~m}, 1 \mathrm{H}), 8.41(\mathrm{t}, J=5.3 \mathrm{~Hz}, 1 \mathrm{H}) .{ }^{13} \mathrm{C}$ NMR $\left(100.5 \mathrm{MHz}, \mathrm{DMSO}-\mathrm{d}_{6}\right), \delta(\mathrm{ppm}): 37.0,52.7$, 
52.9, 57.1, 62.2, 112.5, 117.3, 119.3, 122.4, 126.6, 126.9, 128.2, 128.6, 129.4, 132.2, 138.3, 153.3, 158.1, 166.4 . HRMS $[\mathrm{M}+\mathrm{H}]^{+}$: calculated 456.2394; found 456.2375.

\section{Conclusions}

In this paper, we have described an efficient condensation-mediated synthesis of 2-hydroxyphenylbenzimidazole derivatives and the whole synthesis of the hit, Donepezil-like compound PZ1, in selected DESs as environmentally responsible, safe, and nonconventional reaction media. Compared to VOCs, the synthesis of 2-hydroxyphenylbenzimidazoles in $\mathrm{ChCl} / \mathrm{gly}$ takes place in better yields, shorter reaction time ( $30 \mathrm{~min}$ vs. $12 \mathrm{~h}$ ) and under milder conditions $\left(50 \mathrm{vs} .100{ }^{\circ} \mathrm{C}\right)$, and provides a way of easy functionalization of the phenolic moiety which may have implication on some important biological properties of these nuclei, such as the effective chelation of heavy metals. Moreover, these adducts were found to precipitate from the eutectic mixture after adding water during the work-up procedure, and thus they could easily be isolated by simple filtration. Further investigation into the application of these ligands in the therapy of Alzheimer's disease are underway in our laboratory and results will be reported in due course.

Author Contributions: L.P. conceived and designed the experiments and wrote the first draft of the paper; R.S., F.R., L.B. and F.M.P. carried out the experimental work; V.C., and M.A.S. provided reagents/materials/analysis tools; L.P., V.C., and F.M.P. analyzed the data and participated in the discussion of the obtained results; V.C. wrote the last draft of the paper and all authors participated in revising it. All authors have read and agreed to the published version of the manuscript.

Funding: This work was carried out under the framework of the national PRIN project "Unlocking Sustainable Technologies Through Nature-inspired Solvents (NATUREChem) (grant number: 2017A5HXFC_002) financially supported by the University of Bari "Aldo Moro", the Interuniversity Consortium C.I.N.M.P.I.S., and the Ministero dell'Università e della Ricerca (MIUR-PRIN).

Acknowledgments: L.P. thanks Fondo di Sviluppo e Coesione 2007-2013-APQ Ricerca Regione Puglia "Programma regionale a sostegno della specializzazione intelligente e della sostenibilità sociale ed ambientale Future In Research", Project ID: I2PCTF6. L.P. and F.R. thank the Erasmus+ EU programme.

Conflicts of Interest: The authors declare no conflict of interest.

\section{References}

1. Cacabelos, R. Have there been improvements in Alzheimer's disease drug discovery over the past 5 years? Expert Opin. Drug Discov. 2018, 13, 523-538. [CrossRef] [PubMed]

2. Piemontese, L.; Loiodice, F.; Chaves, S.; Santos, M.A. The Therapy of Alzheimer's Disease: Towards a New Generation of Drugs. Front. Clin. Drug Res. Alzheimer Disord. 2019, 8, 33-80.

3. Fiest, K.M.; Roberts, J.I.; Maxwell, C.J.; Hogan, D.B.; Smith, E.E.; Frolkis, A.; Cohen, A.; Kirk, A.; Pearson, D.; Pringsheim, T.; et al. The prevalence and incidence of dementia due to Alzheimer's disease: A systematic review and meta-analysis. Can. J. Neurol. Sci. 2016, 43, S51-S82. [CrossRef] [PubMed]

4. GBD 2015. Neurological Disorders Collaborator Group. Global, regional, and national burden of neurological disorders during 1990-2015: A systematic analysis for the Global Burden of Disease Study 2015. Lancet Neurol. 2017, 16, 877-897. [CrossRef]

5. Cummings, J.; Aisen, P.S.; DuBois, B.; Frölich, L.; Jack, C.R.; Jones, R.W.; Morris, J.C.; Raskin, J.; Dowsett, S.A.; Scheltens, P. Drug development in Alzheimer's disease: The path to 2025. Alzheimers Res. Ther. 2016, 8, 39. [CrossRef] [PubMed]

6. Cummings, J.L.; Morstorf, T.; Zhong, K. Alzheimer's disease drug-development pipeline: Few candidates, frequent failures. Alzheimers Res. Ther. 2014, 6, 37. [CrossRef]

7. Cummings, J.; Lee, G.; Mortsdorf, T.; Ritter, A.; Zhong, K. Alzheimer's disease drug development pipeline: 2019. Alzheimers Dement. 2019, 5, 272-293. [CrossRef]

8. Dudley, J.; Berliocchi, L. Drug Repositioning: Approaches and Applications for Neurotherapeutic; Taylor\&Francis Group, CRC Press: Boca Raton, FL, USA, 2017; ISBN 9781482220834.

9. Guzior, N.; Wieckowska, A.; Panek, D.; Malawska, B. Recent development of multifunctional agents as potential drug candidates for the treatment of Alzheimer's disease. Curr. Med. Chem. 2015, 22, 373-404. [CrossRef] 
10. Das, S.; Basu, S. Multi-targeting strategies for alzheimer's disease therapeutics: Pros and cons. Curr. Top. Med. Chem. 2017, 17, 3017-3061. [CrossRef]

11. Piemontese, L. New approaches for prevention and treatment of Alzheimer's disease: A fascinating challenge. Neural Regen. Res. 2017, 12, 405-406. [CrossRef]

12. Mattson, M.P. Pathways towards and away from Alzheimer's disease. Nature 2004, 430, 631-639. [CrossRef] [PubMed]

13. Daoud, I.; Melkemi, N.; Salah, T.; Ghalem, S. Combined QSAR, molecular docking and molecular dynamics study on new Acetylcholinesterase and Butyrylcholinesterase inhibitors. Comput. Biol. Chem. 2018, 74, 304-326. [CrossRef] [PubMed]

14. Darvesh, S.; Hopkins, D.A.; Geula, C. Neurobiology of butyrylcholinesterase. Nat. Rev. Neurosci. 2003, 4, 131-138. [CrossRef] [PubMed]

15. Greig, N.H.; Lahiri, D.K.; Sambamurti, K.; Kumar, S. Butyrylcholinesterase: An important new target in Alzheimer's disease therapy. Int. Psychogeriatr. 2002, 14 (Suppl. 1), 77-91. [CrossRef]

16. Rivera, I.; Capone, R.; Cauvi, D.M.; Arispe, N.; De Maio, A. Modulation of Alzheimer's amyloid $\beta$ peptide oligomerization and toxicity by extracellular Hsp70. Cell. Stress Chaperones 2018, 23, 269-279. [CrossRef]

17. Chaves, S.; Piemontese, L.; Hiremathad, A.; Santos, M.A. Hydroxypyridinone Derivatives: A Fascinating Class of Chelators with Therapeutic Applications-An Update. Curr. Med. Chem. 2018, 25, 97-112. [CrossRef]

18. Crews, L.; Masliah, E. Molecular mechanisms of neurodegeneration in Alzheimer's disease. Hum. Mol. Genet. 2010, 19, R12-R20. [CrossRef]

19. Piemontese, L.; Tomás, D.; Hiremathad, A.; Capriati, V.; Candeias, E.; Cardoso, S.M.; Chaves, S.; Santos, M.A. Donepezil structure-based hybrids as potential multifunctional anti-Alzheimer's drug candidates. J. Enzyme Inhib. Med. Chem. 2018, 33, 1212-1224. [CrossRef]

20. Hiremathad, A.; Keri, R.S.; Esteves, A.R.; Cardoso, S.M.; Chaves, S.; Santos, M.A. Novel TacrineHydroxyphenylbenzimidazole hybrids as potential multitarget drug candidates for Alzheimer's disease. Eur. J. Med. Chem. 2018, 148, 255-267. [CrossRef]

21. Chaves, S.; Hiremathad, A.; Tomás, D.; Keri, R.S.; Piemontese, L.; Santos, M.A. Exploring the chelating capacity of 2-hydroxyphenyl-benzimidazole based hybrids with multi-target ability as anti-Alzheimer's agents. New J. Chem. 2018, 42, 16503-16515. [CrossRef]

22. Salahuddin; Shaharyar, M.; Mazumder, A. Benzimidazoles: A biologically active compounds. Arab. J. Chem. 2017, 10, S157-S173.

23. Singh, V.K.; Parle, A. The intriguing benzimidazole: A review. Int. J. Pharm. Sci. Res. 2019, 10, 1540-1552.

24. Singh, P.K.; Silakari, O. Benzimidazole: Journey from Single Targeting to Multitargeting Molecule. In Key Heterocycle Cores for Designing Multitargeting Molecules, 1st ed.; Silakari, O., Ed.; Elsevier Ltd.: Amsterdam, The Netherland, 2018; pp. 31-52.

25. Gulcan, H.O.; Mavideniz, A.; Sahin, M.F.; Orhan, I.E. Benzimidazole-derived Compounds Designed for Different Targets of Alzheimer's Disease. Curr. Med. Chem. 2019, 26, 3260-3278. [CrossRef] [PubMed]

26. Hiremathad, A.; Piemontese, L. Heterocyclic compounds as key structures for the interaction with old and new targets in Alzheimer's disease therapy. Neural Regen. Res. 2017, 12, 1256-1261. [PubMed]

27. Piemontese, L.; Vitucci, G.; Catto, M.; Laghezza, A.; Perna, F.M.; Rullo, M.; Loiodice, F.; Capriati, V.; Solfrizzo, M. Natural Scaffolds with Multi-Target Activity for the Potential Treatment of Alzheimer's Disease. Molecules 2018, 23, 2182. [CrossRef] [PubMed]

28. Deep Eutectic Solvents: Synthesis, Properties, and Applications, 1st ed.; Ramón, D.J.; Guillena, G. (Eds.) Wiley-VCH: Weinheim, Germany, 2019; pp. 1-384.

29. Alonso, D.A.; Baeza, A.; Chinchilla, R.; Guillena, G.; Pastor, I.M.; Ramón, D.J. Deep Eutectic Solvents: The Organic Reaction Medium of the Century. Eur. J. Org. Chem. 2016, 612-632. [CrossRef]

30. Perna, F.M.; Vitale, P.; Capriati, V. Deep eutectic solvents and their applications as green solvents. Curr. Opin. Green Sust. Chem. 2020, 21, 27-33. [CrossRef]

31. Paradiso, V.M.; Clemente, A.; Summo, C.; Pasqualone, A.; Caponio, F. Towards green analysis of virgin olive oil phenolic compounds: Extraction by a natural deep eutectic solvent and direct spectrophotometric detection. Food Chem. 2016, 212, 43-47. [CrossRef]

32. Piemontese, L.; Perna, F.M.; Logrieco, A.; Capriati, V.; Solfrizzo, M. Deep Eutectic Solvents as Novel and Effective Extraction Media for Quantitative Determination of Ochratoxin A in Wheat and Derived Products. Molecules 2017, 22, 121. [CrossRef] 
33. Pena-Pereira, F.; Namieśnik, J. Ionic liquids and deep eutectic mixtures: Sustainable solvents for extraction processes. ChemSusChem 2014, 7, 1784-1800. [CrossRef]

34. Tang, B.; Zhang, H.; Row, K.H. Application of deep eutectic solvents in the extraction and separation of target compounds from various samples. J. Sep. Sci. 2015, 38, 1053-1064. [CrossRef] [PubMed]

35. Carriazo, D.; Serrano, M.C.; Gutiérrez, M.C.; Ferrer, M.L.; del Monte, F. Deep-eutectic solvents playing multiple roles in the synthesis of polymers and related materials. Chem. Soc. Rev. 2012, 41, 4996-5014. [CrossRef] [PubMed]

36. Smith, E.L.; Abbott, A.P.; Ryder, K.S. Deep Eutectic Solvents (DESs) and Their Applications. Chem. Rev. 2014, 114, 11060-11082. [CrossRef] [PubMed]

37. Shahiri-Haghayegh, M.; Azizi, N. DESs as Catalyst. In Deep Eutectic Solvents: Synthesis, Properties, and Applications, 1st ed.; Ramón, D.J., Guillena, G., Eds.; Wiley-VCH: Weinheim, Germany, 2019; pp. $135-170$.

38. García-Álvarez, J.; Hevia, E.; Capriati, V. Reactivity of Polar Organometallic Compounds in Unconventional Reaction Media: Challenges and Opportunities. Eur. J. Org. Chem. 2015, 6779-6799. [CrossRef]

39. Cicco, L.; Rodríguez-Álvarez, M.J.; Perna, F.M.; García-Álvarez, J.; Capriati, V. One-pot sustainable synthesis of tertiary alcohols by combining ruthenium-catalysed isomerisation of allylic alcohols and chemoselective addition of polar organometallic reagents in deep eutectic solvents. Green Chem. 2017, 19, 3069-3077. [CrossRef]

40. García-Álvarez, J.; Hevia, E.; Capriati, V. The Future of Polar Organometallic Chemistry Written in Bio-Based Solvents and Water. Chem. Eur. J. 2018, 24, 14854-14863. [CrossRef]

41. Lu, J.; Li, X.T.; Ma, E.Q.; Mo, L.P.; Zhang, Z.H. Superparamagnetic $\mathrm{CuFeO}_{2}$ Nanoparticles in Deep Eutectic Solvent: An Efficient and Recyclable Catalytic System for the Synthesis of Imidazo[1,2-a]pyridines. ChemCatChem 2014, 6, 2854-2859. [CrossRef]

42. Marset, X.; Khoshnood, A.; Sotorríos, L.; Gjmez-Bengoa, E.; Alonso, D.A.; Ramón, D.J. Deep Eutectic Solvent Compatible Metallic Catalysts: Cationic Pyridiniophosphine Ligands in Palladium Catalyzed Cross-Coupling Reactions. ChemCatChem 2017, 9, 1269-1275. [CrossRef]

43. Ghinato, S.; Dilauro, G.; Perna, F.M.; Capriati, V.; Blangetti, M.; Prandi, C. Directed ortho-metalation-nucleophilic acyl substitution strategies in deep eutectic solvents: The organolithium base dictates the chemoselectivity. Chem. Commun. 2019, 55, 7741-7744. [CrossRef]

44. Dilauro, G.; García, S.M.; Tagarelli, D.; Vitale, P.; Perna, F.M.; Capriati, V. Ligand-Free Bioinspired Suzuki-Miyaura Coupling Reactions using Aryltrifluoroborates as Effective Partners in Deep Eutectic Solvents. ChemSusChem 2018, 11, 3495-3501. [CrossRef]

45. Quivelli, A.F.; Vitale, P.; Perna, F.M.; Capriati, V. Reshaping Ullmann Amine Synthesis in Deep Eutectic Solvents: A Mild Approach for Cu-Catalyzed C-N Coupling Reactions With No Additional Ligands. Front. Chem. 2019, 7, 723. [CrossRef] [PubMed]

46. Messa, F.; Perrone, S.; Capua, M.; Tolomeo, F.; Troisi, L.; Capriati, V.; Salomone, A. Towards a sustainable synthesis of amides: Chemoselective palladium-catalysed aminocarbonylation of aryl iodides in deep eutectic solvents. Chem. Commun. 2018, 54, 8100-8103. [CrossRef] [PubMed]

47. Messa, F.; Dilauro, G.; Perna, F.M.; Vitale, P.; Capriati, V.; Salomone, A. Sustainable Ligand-Free Heterogeneous Palladium-Catalyzed Sonogashira Cross-Coupling Reaction in Deep Eutectic Solvents. ChemCatChem 2020, (in press). [CrossRef]

48. Marset, X.; Saavedra, B.; González-Gallardo, N.; Beaton, A.; León, M.M.; Luna, R.; Ramón, D.J.; Guillena, G. Palladium Mesoionic Carbene Pre-catalyst for general Cross-Coupling Transformations in Deep Eutectic Solvents. Front. Chem. 2019, 7, 700. [CrossRef] [PubMed]

49. Meller, C.R.; Meiners, I.; Domínguez de María, P. Highly enantioselective tandem enzyme-organocatalyst crossed aldol reactions with acetaldehyde in deep-eutectic-solvents. RSC Adv. 2014, 4, 46097-46101. [CrossRef]

50. Sheldon, A.R. Biocatalysis and Biomass Conversion in Alternative Reaction Media. Chem. Eur. J. 2016, 22, 12984-12999. [CrossRef]

51. Vitale, P.; Abbinante, V.M.; Perna, F.M.; Salomone, A.; Cardellicchio, C.; Capriati, V. Unveiling the Hidden Performance of Whole Cells in the Asymmetric Bioreduction of Aryl-containing Ketones in Aqueous Deep Eutectic Solvents. Adv. Synth. Catal. 2017, 359, 1049-1057. [CrossRef]

52. Vitale, P.; Perna, F.M.; Agrimi, G.; Pisano, I.; Mirizzi, F.; Capobianco, V.R.; Capriati, V. Whole-Cell Biocatalyst for Chemoenzymatic Total Synthesis of Rivastigmine. Catalysts 2018, 8, 55. [CrossRef] 
53. Cicco, L.; Ríos-Lombardía, N.; Rodríguez-Álvarez, M.J.; Moris, F.; Perna, F.M.; Capriati, V.; García-Álvarez, J.; González-Sabín, J. Programming cascade reactions interfacing biocatalysis with transition-metal catalysis in Deep Eutectic Solvents as biorenewable reaction media. Green Chem. 2018, 20, 3468-3475. [CrossRef]

54. Martínez, R.; Berbegal, L.; Guillena, G.; Ramón, D.J. Bio-renewable enantioselective aldol reaction in natural deep eutectic solvents. Green Chem. 2016, 18, 1724-1730. [CrossRef]

55. Massolo, E.; Palmieri, S.; Benaglia, M.; Capriati, V.; Perna, F.M. Stereoselective organocatalysed reactions in deep eutectic solvents: Highly tunable and biorenewable reaction media for sustainable organic synthesis. Green Chem. 2016, 18, 792-797. [CrossRef]

56. Brenna, D.; Massolo, E.; Puglisi, A.; Rossi, S.; Celentano, G.; Benaglia, M.; Capriati, V. Towards the development of continuous, organocatalytic, and stereoselective reactions in deep eutectic solvents. Beilstein J. Org. Chem. 2016, 12, 2620-2626. [CrossRef] [PubMed]

57. Torregrosa-Chinillach, A.; Sánchez-Laó, A.; Santagostino, E.; Chinchilla, R. Organocatalytic Asymmetric Conjugate Addition of Aldehydes to Maleimides and Nitroalkenes in Deep Eutectic Solvents. Molecules 2019, 24, 4058. [CrossRef] [PubMed]

58. Milla, L.; Dall'Asta, V.; Ferrara, C.; Berbenni, V.; Quartarone, E.; Perna, F.M.; Capriati, V.; Mustarelli, P. Bio-inspired choline chloride-based deep eutectic solvents as electrolytes for lithium-ion batteries. Solid State Ionics 2018, 323, 44-48. [CrossRef]

59. Milano, F.; Giotta, L.; Guascito, M.R.; Agostiano, A.; Sblendorio, S.; Valli, L.; Perna, F.M.; Cicco, L.; Trotta, M.; Capriati, V. Functional Enzymes in Nonaqueous Environment: The Case of Photosynthetic Reaction Centers in Deep Eutectic Solvents. ACS Sustain. Chem. Eng. 2017, 5, 7768-7776. [CrossRef]

60. Boldrini, C.L.; Manfredi, N.; Perna, F.M.; Trifiletti, V.; Capriati, V.; Abbotto, A. Dye-Sensitized Solar Cells that use an Aqueous Choline Chloride-Based Deep Eutectic Solvent as Effective Electrolyte Solution. Energy Technol. 2017, 5, 345-353. [CrossRef]

61. Boldrini, C.L.; Manfredi, N.; Perna, F.M.; Capriati, V.; Abbotto, A. Designing Eco-Sustainable Dye-Sensitized Solar Cells by the Use of a Menthol-Based Hydrophobic Eutectic Solvent as an Effective Electrolyte Medium. Chem. Eur. J. 2018, 24, 17656-17659. [CrossRef]

62. Capua, M.; Perrone, S.; Perna, F.M.; Vitale, P.; Troisi, L.; Salomone, A.; Capriati, V. An Expeditious and Greener Synthesis of 2-Aminoimidazoles in Deep Eutectic Solvents. Molecules 2016, 21, 924. [CrossRef]

63. Mancuso, R.; Maner, A.; Cicco, L.; Perna, F.M.; Capriati, V.; Gabriele, B. Synthesis of thiophenes in a deep eutectic solvent: Heterocyclodehydration and iodocyclization of 1-mercapto-3-yn-2-ols in a choline chloride/glycerol medium. Tetrahedron 2016, 72, 4239-4244. [CrossRef]

64. Dilauro, G.; Quivelli, A.F.; Vitale, P.; Capriati, V.; Perna, F.M. Water and sodium chloride: Essential ingredients for robust and fast Pd-catalysed cross-coupling reactions between organolithium reagents and (hetero)aryl halides. Angew. Chem. Int. Ed. 2019, 58, 1799-1802. [CrossRef]

65. Lee, J.-Y.; Mook-Jung, I.; Koh, J.-Y. Histochemically Reactive Zinc in Plaques of the Swedish Mutant $\beta$-Amyloid Precursor Protein Transgenic Mice. J. Neurosci. 1999, 19, RC10. [CrossRef] [PubMed]

66. Lovell, M.A.; Robertson, J.D.; Teesdale, W.J.; Campbell, J.L.; Markesbery, W.R. Copper, iron and zinc in Alzheimer's disease senile plaques. J. Neurol. Sci. 1998, 158, 47-52. [CrossRef]

67. Suh, S.W.; Jensen, K.B.; Jensen, M.S.; Silva, D.S.; Kesslak, P.J.; Danscher, G.; Frederickson, C.J. Histochemically-reactive zinc in amyloid plaques, angiopathy, and degenerating neurons of Alzheimer's diseased brains. Brain Res. 2000, 852, 274-278. [CrossRef]

68. Liang, S.H.; Southon, A.G.; Fraser, B.H.; Krause-Heuer, A.M.; Zhang, B.; Shoup, T.M.; Lewis, R.; Volitakis, I.; Han, Y.; Greguric, I.; et al. Novel Fluorinated 8-Hydroxyquinoline Based Metal Ionophores for Exploring the Metal Hypothesis of Alzheimer's Disease. ACS Med. Chem. Lett. 2015, 6, 1025-1029. [CrossRef] [PubMed]

69. Cherny, R.A.; Atwood, C.S.; Xilinas, M.E.; Gray, D.N.; Jones, W.D.; McLean, C.A.; Barnham, K.J.; Volitakis, I.; Fraser, F.W.; Kim, Y.-S.; et al. Treatment with a Copper-Zinc Chelator Markedly and Rapidly Inhibits A $\beta$-Amyloid Accumulation in Alzheimer's Disease Transgenic Mice. Neuron 2001, 30, 665-676. [CrossRef]

70. Zagidullin, R.N. Reactions of N-( $\beta$-aminoethyl)piperazine and its derivatives. Chem. Heterocycl. Comp. 1991, 27, 309-312. [CrossRef]

71. Yusof, R.; Abdulmalek, E.; Sirat, K.; Basyaruddin, M.; Rahman, A. Tetrabutylammonium Bromide (TBABr)-Based Deep Eutectic Solvents (DESs) and Their Physical Properties. Molecules 2014, 19, 8011-8026. [CrossRef] 
72. Mjalli, F.S.; Naser, J.; Jibril, B.; Alizadeh, V.; Gano, Z. Tetrabutylammonium Chloride Based Ionic Liquid Analogues and Their Physical Properties. J. Chem. Eng. Data 2014, 59, 2242-2251. [CrossRef]

73. Warrag, S.E.E.; Kroon, M.C. Hydrophobic Deep Eutectic Solvents. In Deep Eutectic Solvents: Synthesis, Properties, and Applications, 1st ed.; Ramón, D.J., Guillena, G., Eds.; Wiley-VCH: Weinheim, Germany, 2019; pp. 83-93.

74. Porcelli, L.; Gilardi, F.; Laghezza, A.; Piemontese, L.; Mitro, N.; Azzariti, A.; Altieri, F.; Cervoni, L.; Fracchiolla, G.; Giudici, M.; et al. Synthesis, characterization and biological evaluation of ureidofibrate-like derivatives endowed with peroxisome proliferator-activated receptor activity. J. Med. Chem. 2012, 55, 37-54. [CrossRef]

75. Available online: https://www.alzforum.org/therapeutics/clioquinol (accessed on 11 November 2019).

76. Baldisserotto, A.; Demurtas, M.; Lampronti, I.; Tacchini, M.; Moi, D.; Balboni, G.; Pacifico, S.; Vertuani, S.; Manfredini, S.; Onnis, V. Synthesis and evaluation of antioxidant and antiproliferative activity of 2-arylbenzimidazoles. Bioorg. Chem. 2019, (in press). [CrossRef]

77. Karthikeyan, C.; Solomon, V.R.; Lee, H.; Trivedi, P. Synthesis and biological evaluation of 2-(phenyl)-3H-benzo[d]imidazole-5-carboxylic acids and its methyl esters as potent anti-breast cancer agents. Arab. J. Chem. 2017, 10, S1788-S1794. [CrossRef]

78. Di Gioia, M.L.; Cassano, R.; Costanzo, P.; Herrera Cano, N.; Maiuolo, L.; Nardi, M.; Nicoletta, F.P.; Oliverio, M.; Procopio, A. Green Synthesis of Privileged Benzimidazole Scaffolds Using Active Deep Eutectic Solvent. Settings. Molecules 2019, 24, 2885. [CrossRef] [PubMed]

Sample Availability: Samples of the compounds are not available from the authors.

(C) 2020 by the authors. Licensee MDPI, Basel, Switzerland. This article is an open access article distributed under the terms and conditions of the Creative Commons Attribution (CC BY) license (http://creativecommons.org/licenses/by/4.0/). 